International Journal of

Molecular Sciences

ISSN 1422-0067

www.mdpi.com/journal/ijms

Review

\title{
Transforming Growth Factor-Beta-Induced Protein (TGFBI)/(ßig-H3): A Matrix Protein with Dual Functions in Ovarian Cancer
}

\author{
Miranda P. Ween ${ }^{1,2}$, Martin K. Oehler ${ }^{1,3}$ and Carmela Ricciardelli ${ }^{1, *}$
}

1 Discipline of Obstetrics and Gynaecology, School of Paediatrics and Reproductive Health, Research Centre for Reproductive Health, Robinson Institute, University of Adelaide, Adelaide, South Australia, 5000, Australia; E-Mails: miranda.ween@adelaide.edu.au (M.P.W.); martin.oehler@adelaide.edu.au (M.K.O.)

2 Research Centre for Infectious Diseases, School of Molecular Biosciences, University of Adelaide, South Australia 5005, Australia

3 Department of Gynaecological Oncology, Royal Adelaide Hospital, Adelaide, South Australia, 5000, Australia

* Author to whom correspondence should be addressed;

E-Mail: carmela.ricciardelli@adelaide.edu.au; Tel.: +61-8-8313-8255; Fax: +61-8-8313-4099.

Received: 30 June 2012; in revised form: 3 August 2012 / Accepted: 16 August 2012 /

Published: 21 August 2012

Abstract: Transforming growth factor-beta-induced protein (TGFBI, also known as Big-H3 and keratoepithelin) is an extracellular matrix protein that plays a role in a wide range of physiological and pathological conditions including diabetes, corneal dystrophy and tumorigenesis. Many reports indicate that $\beta$ ig-H3 functions as a tumor suppressor. Loss of $\beta$ ig-H3 expression has been described in several cancers including ovarian cancer and promoter hypermethylation has been identified as an important mechanism for the silencing of the TGFBI gene. Our recent findings that $\beta$ ig-H3 is down-regulated in ovarian cancer and that high concentrations of $\beta$ ig- 33 can induce ovarian cancer cell death support a tumor suppressor role. However, there is also convincing data in the literature reporting a tumor-promoting role for $\beta$ ig-H3. We have shown $\beta$ ig-H3 to be abundantly expressed by peritoneal cells and increase the metastatic potential of ovarian cancer cells by promoting cell motility, invasion, and adhesion to peritoneal cells. Our findings suggest that $\beta$ ig-H3 has dual functions and can act both as a tumor suppressor or tumor promoter depending on 
the tumor microenvironment. This article reviews the current understanding of $\beta$ ig- $\mathrm{H} 3$ function in cancer cells with particular focus on ovarian cancer.

Keywords: ovarian cancer; extracellular matrix; TGFBI; tumor suppressor; invasion; adhesion; metastasis

\section{Introduction}

Big-H3 (also known as TGFBI for protein and TGFBI for gene) is a transforming growth factor beta (TGF $\beta$ ) inducible secreted extracellular matrix (ECM) protein. The name $\beta$ ig-H3 was derived from its cloning as a major TGF $\beta$ responsive gene in lung adenocarcinoma cell line A549: TGF $\beta$ induced gene human clone 3 [1]. In the literature it has also been referred to as keratoepithelin [2], collagen fibre associated protein (RGD-CAP) [3], P78/70 [4], Big-h3 [5], $\beta$-igH3 [6], and $\beta$-ig [7]. $\beta i g-H 3$ is comprised of 683 amino acids and its secreted form has a predicted molecular mass of $68 \mathrm{kDa}$. Two isoforms of $\beta \mathrm{ig}-\mathrm{H} 3$ at 78 and $68 \mathrm{kDa}$ have been reported to date [8], both of which are encoded by a single gene, TGFBI [9]. $\beta$ ig-H3 contains an $N$-terminal secretory signal (1-24 amino acids), a cysteine rich domain, four internal repetitive fasciclin-1 domains (FAS1 1-4), integrin binding motifs in the $C$-terminus known as Arg-Gly-Asp (RGD), YH18, and EPDIM and an internal NKDIL motif [10,11] (Figure 1).

Figure 1. Schematic diagram of Transforming growth factor-beta-induced protein ( $\beta$ ig-H3) protein structure. Secretory signal (SP) in the $N$-terminal cysteine rich domain (CRD), and four fasciclin-1 domains (FAS1 1-4). Position of several known integrin binding motifs, including NKDIL, YH18, EPDIM and Arg-Gly-Asp (RGD), are indicated.

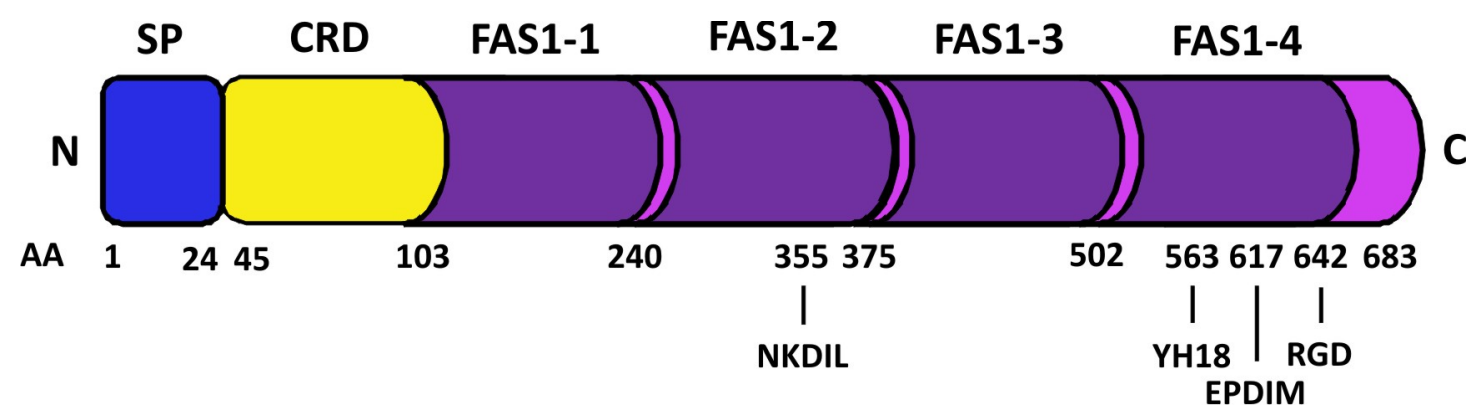

\section{Big-H3 Regulation and Function}

Big-H3 participates in many physiological processes including morphogenesis, adhesion/migration, angiogenesis, and inflammation [12]. It also has a role in reproduction [13,14] and wound healing $[15,16]$. A wide range of cells have been shown to induce expression of $\beta$ ig-H3 following treatment with TGF $\beta$ including, fibroblasts, chondrocytes, smooth muscle cells, corneal epithelial cells, and various types of cancer cells [12]. $\beta$ ig-H3 is regulated not only by TGF $\beta$, but also by retinoid [17], IL-4 [15], IL-1 [18], and TNF- $\alpha$ [18] in various cell types. TNF-like ligand 1A can regulate the inflammatory processes in a human acute monocytic leukemia cell line (THP-1) through 
modulation of the $\beta$ ig- $\mathrm{H} 3$ expression via both protein kinase $\mathrm{C}$ and extracellular signal-regulated kinase pathways [19]. Big-H3 could also be induced in human mesenchymal stem cells by treatment with the phospholipid, lysophosphatidic acid that is enriched in the serum of cancer patients [20]. Recent evidence suggests that $\beta$ ig-H3 expression can also be regulated by the microRNA, miR-21 [5]. Big-H3 has been shown to trigger phosphorylation and to activate several intracellular pathways including AKT, extracellular signal-regulated kinase, focal adhesion kinase (FAK), and paxillin, thus mediating adhesion and migration of vascular smooth muscle cells through interactions with $\alpha v \beta 5$ integrins [21].

Immunohistochemical studies show that $\beta \mathrm{ig}-\mathrm{H} 3$ is distributed in the ECM of a wide range of developing and mature tissues, including endothelial cells of human vascular tissues [22], papillary dermis [10], primary spongiosa, periosteum, and perichondrium [23]. It has also been associated with bone formation [24,25]. Big-H3 expression is induced in endothelium and stroma-derived cells in the healing cornea [7] and reactive astrocytes in rat cerebral cortex at wound sites [16].

In many cell types, $\beta$ ig-H3 functions as a linker protein which connects various matrix molecules to each other as well as facilitating cell-collagen interactions [4,26-28]. $\beta$ ig-H3 can bind to type I, II, and IV collagens as well as proteoglycans such as biglycan and decorin [28]. It has been shown that $\beta$ ig-H3 binds covalently to collagen VI microfibrils [27] and interacts with fibronectin [26] and various integrins [29], which are the only $\beta$ ig-H3 cell surface receptors identified to date (reviewed in [12]).

Big-H3 plays a role in the adhesion and migration of a wide range of cells including keratinocytes, fibroblasts, chondrocytes, osteoblasts, and endothelial cells (reviewed by [25]). Effects on adhesion are mediated through interactions with various integrins including $\alpha 1 \beta 1, \alpha 3 \beta 1, \alpha v \beta 3$, and $\alpha v \beta 5[10,30-33]$ via integrin binding motifs in the $\beta$ ig-H3 protein. These include the well characterized RGD motif in the $C$-terminus [34] as well as the NKDIL motif (amino acids 354-358) [11] and the EPDIM motif (amino acids 617-621) [11] in the second and fourth FAS-1 domains, respectively (Figure 1). The structural analysis of the NKDIL and EPDIM sequence motifs show that they can adopt a $\beta$-turn structure similar to the RGD motif to interact with integrins during adhesion [34]. Another adhesion motif shown to support $\alpha v \beta 5$ integrin mediated adhesion of lung fibroblast MRC-5 cells [29], vascular smooth muscle cells [21], and endothelial cells [35], is the highly conserved tyrosine and histidine residues YH18 motif (amino acids 563-580) in the fourth FAS-1 domain, which is flanked by several leucine/isoleucine residues (Figure 1).

\section{Big-H3 Roles in Disease}

\subsection{Role in Diabetes and Corneal Dystrophies}

Big-H3 has been associated with a range of diseases including nephropathy [36], atherosclerosis [22], and rheumatoid arthritis $[15,18]$, as well as corneal disorders. Its role in inflammatory disease processes is not well understood. Big-H3 expression is prominent in the kidney and increased in the urine of diabetics $[37,38]$. It has been suggested that combined monitoring of albumin excretion rate and urinary $\beta$ ig- $\mathrm{H} 3$ can predict the severity of diabetic nephropathy [39]. $\beta$ ig- $\mathrm{H} 3$ has been shown to induce pericyte apoptosis through its RGD motif, which may constitute an important pathogenic mechanism leading to pericyte loss in diabetes [40]. Recent studies also suggest that $\beta$ ig-H3 may be 
involved in kidney pathology associated with preeclampsia, and was detectable in the urine of these patients but not in non-preeclamptic pregnant women [41].

Mutations in the TGFBI gene are well characterized in a number of corneal dystrophies, which lead to the development of corneal deposits and impaired vision [42-45]. Corneal dystrophies represent the only known pathological disease associated with mutations in TGFBI. The mechanisms of pathogenesis are unknown but mutations in TGFBI may impair protein folding or ßig-H3 secretion and result in the deposition and accumulation of mutant $\beta$ ig- $\mathrm{H} 3$ protein that has increased stability [46].

\subsection{Roles in Cancer}

\subsubsection{Role as Tumor Suppressor}

Many reports indicate $\beta$ ig- $\mathrm{H} 3$ is an inhibitor of tumorigenesis and suggest that $\beta \mathrm{ig}-\mathrm{H} 3$ functions as a tumor suppressor (summarized in Table 1). Furthermore, reduced expression of $\beta$ ig-H3 has been observed in many tumor types. Down-regulation of $\beta$ ig-H3 was found to correlate highly with promoter hypermethylation in lung, prostate, and breast cancer cells. Promoter hypermethylation is considered an important mechanism involved in the silencing of the TGFBI gene in human cancer cells [47].

Table 1. Studies reporting a tumor suppressor role for $\beta$ ig- $\mathrm{H} 3$.

\begin{tabular}{|c|c|c|}
\hline Cell Type & Observation & References \\
\hline \multirow{2}{*}{$\mathrm{CHO}$ cells } & $\begin{array}{l}\text { Big-H3 inhibits cell attachment in vitro and suppresses the growth of } \\
\text { CHO tumor cells in nude mice }\end{array}$ & [48] \\
\hline & $\begin{array}{l}\text { RGD peptides released from } \beta \text { ig- } \mathrm{H} 3 \text { mediate apoptosis of } \mathrm{CHO} \text { tumor } \\
\text { cells }\end{array}$ & [49] \\
\hline HeLa cells & $\begin{array}{l}\text { RGD peptides released from } \beta \text { ig-H3 mediate apoptosis of HeLa tumor } \\
\text { cells }\end{array}$ & [49] \\
\hline \multirow{3}{*}{ Bronchial epithelial cells } & $\begin{array}{l}\text { Big-H3 overexpression suppresses tumorigenicity in radiation-induced } \\
\text { tumorigenic human bronchial epithelial cells }\end{array}$ & {$[50]$} \\
\hline & $\begin{array}{l}\text { Loss of } \beta i g-\mathrm{H} 3 \text { expression is associated with the tumorigenic } \\
\text { phenotype in asbestos-treated bronchial epithelial cells }\end{array}$ & {$[51]$} \\
\hline & $\begin{array}{l}\text { Big-H3 gene down-regulation is involved in heavy-ion } \\
\text { radiation-induced tumorigenesis of human bronchial epithelial cells }\end{array}$ & {$[52]$} \\
\hline \multirow{5}{*}{ Lung adenocarcinoma } & $\begin{array}{l}\text { Loss of } \beta \text { ig- } \mathrm{H} 3 \text { protein is frequent in primary lung carcinoma and } \\
\text { related to tumorigenic phenotype in lung cancer cells }\end{array}$ & {$[53]$} \\
\hline & $\begin{array}{l}\text { Promoter methylation contributes to promoter silencing of the } \beta \text { ig-H3 } \\
\text { gene in human lung cancer cells }\end{array}$ & {$[47]$} \\
\hline & $\begin{array}{l}\text { Big-H3 is down-regulated in radiation-induced thymic lymphoma } \\
\text { model in BALB/c mice }\end{array}$ & {$[5]$} \\
\hline & $\begin{array}{l}\text { Big-H3 overexpression in } \mathrm{H} 522 \text { lung carcinoma cells reduces motility } \\
\text { in vitro and metastasis in vivo }\end{array}$ & {$[54]$} \\
\hline & $\begin{array}{l}\text { RGD } \beta \text { ig-H3 peptides mediate apoptosis of H1299 lung carcinoma } \\
\text { cells }\end{array}$ & [49] \\
\hline Mesothelioma cell lines & $\begin{array}{l}\text { Big-H3 knockdown increases proliferation and anchorage independent } \\
\text { growth of mesothelioma cell lines }\end{array}$ & {$[55]$} \\
\hline
\end{tabular}


Table 1. Cont.

\begin{tabular}{|c|c|c|}
\hline Cell Type & Observation & References \\
\hline \multirow{2}{*}{ Breast carcinoma } & $\begin{array}{l}\text { Big- } \mathrm{H} 3 \text { protein expression is reduced in in situ ductal carcinoma and } \\
\text { breast carcinoma tissues, compared to benign tissues }\end{array}$ & [54] \\
\hline & $\begin{array}{l}\text { Big-H3 overexpression in MCF- } 7 \text { cells reduces motility in vitro and } \\
\text { metastasis in vivo }\end{array}$ & [54] \\
\hline Neuroblastoma & $\begin{array}{l}\text { Big-H3 significantly reduces proliferation and invasion of } \\
\text { neuroblastoma cell in vitro and in vivo }\end{array}$ & {$[2,56]$} \\
\hline Osteosarcoma & $\begin{array}{l}C \text {-terminal fragment of } \beta i g-\mathrm{H} 3 \text { is required for apoptosis in human } \\
\text { osteosarcoma cells }\end{array}$ & [57] \\
\hline Hepatoma & RGD ßig-H3 peptides mediate apoptosis of Hep3B hepatoma cells & [47] \\
\hline Knockout mice & Big-H3 knockout mice are prone to spontaneous tumors & [58] \\
\hline \multirow{3}{*}{ Ovarian carcinoma } & $\begin{array}{l}\text { Big-H3 silencing and promoter hypermethylation is a frequent } \\
\text { occurrence in ovarian cancer cell lines and ovarian cancer tissues }\end{array}$ & {$[59,60]$} \\
\hline & $\begin{array}{l}\text { Big- } \mathrm{H} 3 \text { is down-regulated in serous ovarian carcinoma and borderline } \\
\text { serous ovarian tumors }\end{array}$ & [61] \\
\hline & Big-H3 induces apotosis in serous ovarian carcinoma cell lines & [61] \\
\hline
\end{tabular}

Big-H3 overexpression has been shown to markedly reduce tumorigenicity of $\mathrm{CHO}$ cells and lung cancer cells in vivo [48,50]. Big-H3 expression is markedly suppressed in asbestos- and radiation-induced tumorigenic cells, whilst ectopic expression of $\beta$ ig-H3 significantly suppresses tumorigenicity and progression in human bronchial epithelial cells [50-52]. ßig-H3 has also been reported to mediate apoptosis through the RGD motif in CHO cells [49] and the EPDIM motif in osteosarcoma cells [57]. A recent observation by Becker et al. suggested that increased expression of Big-H3 suppresses neuroblastoma cell adhesion to various ECM proteins, thus inhibiting their proliferation and invasion [2]. More recent studies demonstrating that the loss of $\beta$ ig-H3 predisposes mice to spontaneous tumor development have provided strong in vivo evidence that $\beta$ ig- $\mathrm{H} 3$ functions as a tumor suppressor [58]. Mouse embryonic fibroblasts isolated from $T G F B \Gamma^{1-}$ mice displayed increased frequencies of chromosomal aberration, abnormal mitoses, and enhanced proliferation [58]. The loss of chromosomal integrity may explain the increased tumor tendency in the TGFBI knockout mice.

Recent studies using lung and breast cancer cell lines have also shown that Big-H3 induced adhesion to ECM proteins, but reduced the motility and invasive ability of these cells both in vitro and in vivo [54]. These findings indicate that $\beta \mathrm{ig}-\mathrm{H} 3$ can restrain the metastatic potential of cancer cells and thus support the tumor suppressor function of $\beta$ ig-H3. Stable $\beta$ ig-H3 knockdown mutants established from a mesothelial cell line, Met-5A, exhibited an elevated proliferation rate, enhanced plating efficiency, increased anchorage-independent growth, and a more active PI3K/AKT/mTOR signaling pathway [55]. These findings suggest that $\beta$ ig-H3 may repress mesothelioma tumorigenesis and progression by inhibiting the PI3K/AKT signaling pathway.

\subsubsection{Roles as Tumor Promoter}

Although there is strong evidence that $\beta$ ig- $\mathrm{H} 3$ has a tumor suppressor function, there is also convincing data in the literature reporting a tumor-promoting role for $\beta$ ig- $\mathrm{H} 3$ (summarized in Table 2). 
High $\beta$ ig-H3 expression has been shown for various tumor tissues and cell lines [6,62-70] and in many cancers elevated expression also relates to more aggressive tumors [6,70,71]. Furthermore, several reports indicate that $\beta$ ig- $\mathrm{H} 3$ can mediate cancer cell invasion and metastasis as well as enhance cancer cell extravasation [71-74].

Big-H3 has been shown to mediate lymphatic endothelial migration and adhesion to ECM under low oxygen conditions [75]. These observations suggest that during hypoxia, which commonly occurs in tumors, $\beta$ ig- $\mathrm{H} 3$ may aid the metastatic process by promoting the adhesion to lymphatic endothelial cells. More recently $\beta$ ig-H3 has been shown to be highly expressed by mesenchymal stem cells derived from human adipose tissue and to stimulate proliferation and adhesion of the A459 human lung adenocarcinoma cell line [20]. Furthermore, $\beta$ ig-H3 observed at the invasion front of melanomas co-localized with fibrillar fibronectin/tenascin-C/periostin structures, suggesting an important role for ßig-H3 in ECM deposition and invasive growth of melanoma cells [76]. siRNAs against $\beta$ ig-H3 transfected into human hepatocellular carcinoma cells showed that $\beta \mathrm{ig}-\mathrm{H} 3$ increases the invasive potential of those cells by regulating MMP-2 and -9 secretion [77]. Thus, due to its tumor promoting role $\beta$ ig-H3 is a promising therapeutic target.

Table 2. Studies reporting a tumor-promoting role for $\beta$ ig-H3.

\begin{tabular}{|c|c|c|}
\hline Cell type & Observation & References \\
\hline \multirow[b]{2}{*}{ Lung adenocarcinoma } & Big-H3 is overexpressed in lung cancer & [6] \\
\hline & $\begin{array}{l}\text { Recombinant } \beta \text { ig-H3 stimulates proliferation and cell adhesion of A549 } \\
\text { cells }\end{array}$ & [20] \\
\hline Oesophageal adenocarcinoma & $\begin{array}{l}\text { } \mathrm{ig}-\mathrm{H} 3 \text { is up-regulated in oesophageal adenocarcinoma and esophageal } \\
\text { squamous cell carcinoma tissues and cell lines tissue }\end{array}$ & {$[65,78,79]$} \\
\hline Pancreatic cancer & Big-H3 expression is increased in pancreatic cancer cell lines and tissues & {$[68,80]$} \\
\hline Oral squamous cell carcinoma & Big-H3 expression is increased in oral squamous cell carcinoma tissues & [81] \\
\hline \multirow{3}{*}{ Brain tumors } & $\begin{array}{l}\text { Big-H3 promotes cell adhesion of human astrocytoma cells in vitro via } \\
\text { interactions with } \alpha 6 \beta 4 \text { integrin }\end{array}$ & [72] \\
\hline & Big-H3 expression is elevated in glioblastoma multiforme tissues & [82] \\
\hline & Knockdown of $\beta$ ig-H3 inhibits glioma cell invasion and MMP secretion & [83] \\
\hline \multirow[b]{2}{*}{ Hepatocellular carcinoma } & Big-H3 knockdown reduced invasion of 7721 cells & [73] \\
\hline & $\begin{array}{l}\beta i g-\mathrm{H} 3 \text { interacts with } \alpha 3 \beta 1 \text { integrin to promote adhesion and invasion of } \\
7721 \text { cells }\end{array}$ & [74] \\
\hline \multirow[b]{2}{*}{ Colon carcinoma } & Big-H3 expression is elevated in human colon carcinoma tissues & {$[64,84]$} \\
\hline & $\begin{array}{l}\text { Overexpression of } \beta \text { ig- } \mathrm{H} 3 \text { promotes extravasation and enhances } \\
\text { metastasis of colon cancer cells }\end{array}$ & [71] \\
\hline \multirow{3}{*}{ Renal cell carcinoma } & Big-H3 is up-regulated in clear cell renal carcinoma & {$[63,64]$} \\
\hline & Big-H3 expression is increased in metastastic renal cell carcinoma & [85] \\
\hline & Big-H3 suppression leads to a chemoresistant phenotype & {$[86,87]$} \\
\hline \multirow[t]{2}{*}{ Ovarian carcinoma } & $\begin{array}{l}\text { Recombinant } \beta \text { ig-H3 promotes motility and invasion of OVCAR- } 5 \text { and } \\
\text { SKOV3 cells }\end{array}$ & [61] \\
\hline & $\begin{array}{l}\text { Recombinant } \beta \text { ig-H3 promotes adhesion of OVCAR-3, OVCAR- } 5 \text { and } \\
\text { SKOV } 3 \text { cells }\end{array}$ & [61] \\
\hline
\end{tabular}




\subsubsection{Role of $\beta$ ig-H3 in Ovarian Cancer}

\subsubsection{Tumor Suppressive role of $\beta$ ig-H3 in Ovarian Cancer}

One of the crucial steps in ovarian cancer metastasis involves the implantation of ovarian cancer cells onto the peritoneal lining. As the underlying molecular mechanisms have not been well characterized we have studied the interaction between ovarian cancer and peritoneal cells in vitro. The ECM protein $\beta$ ig-H3 was found to be differentially regulated in the secretome of peritoneal-ovarian cancer cell co-culture. We demonstrated that $\beta$ ig-H3 is abundantly expressed by peritoneal cells and can promote ovarian cancer cell motility, invasion, and adhesion to LP-9 peritoneal cells [61].

Figure 2. $\mathrm{H} \& \mathrm{E}$ and $\beta$ ig-H3 immunostaining of ovarian tissues. (a) Normal ovary surface epithelium; (b) Benign serous cystadenoma; (c) Serous ovarian carcinoma. Scale bar $=100 \mu \mathrm{m}$ for all images. Immunostaining with polyclonal rabbit $\beta$ ig-H3 antibody (Santa Cruz Biotechnology) as described in [61].

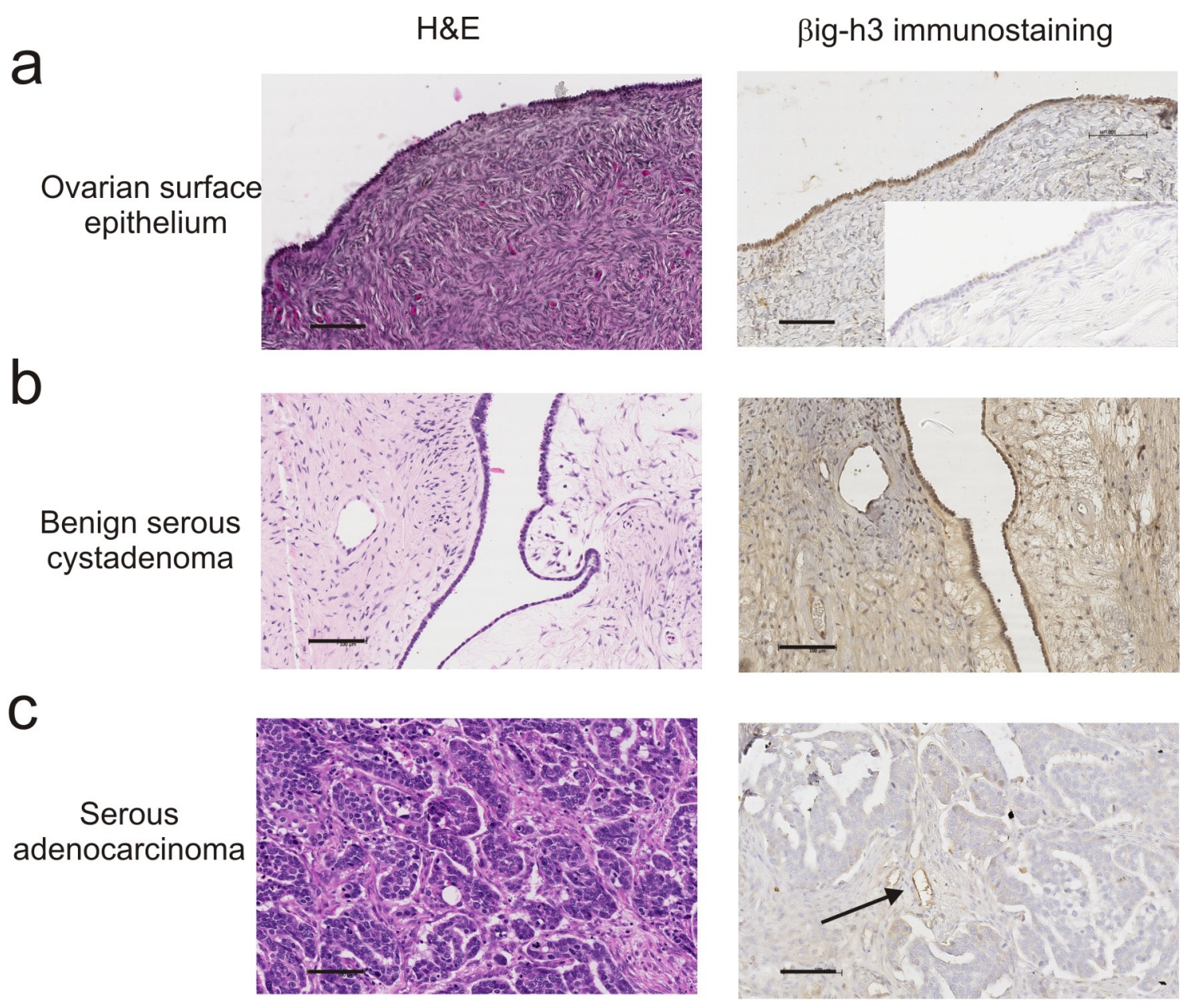

Our recent studies investigating the role of $\beta$ ig-H3 in ovarian tumorigenesis have demonstrated low expression of $\beta$ ig-H3 in ovarian cancer cell lines and ovarian cancer tissue [61]. This is consistent with other studies demonstrating a down-regulation of $\beta i g-H 3$ in cancer cells and more recent studies demonstrating that the $T G F B I$ gene is frequently hypermethylated in ovarian tumors $[59,60]$. Our data, showing high levels of $\beta$ ig-H3 immunostaining in normal ovarian surface epithelial cells (Figure 2a) 
and benign serous ovarian tumors (Figure 2b) but low $\beta$ ig-H3 immunostaining in human serous ovarian cancer cells (Figure 2c), suggest that $\beta$ ig-H3 is down-regulated during the process of ovarian cancer tumorigenesis [61]. Our findings, that high concentrations $(>5 \mu \mathrm{g} / \mathrm{mL})$ of $\beta$ ig- $\mathrm{H} 3$ can induce ovarian cancer cell death, also support an anti-tumorigenic role for $\beta$ ig-H3 [61]. The use of TGFBI methylation as novel epigenetic biomarker for discriminating ovarian cancer from non-cancer or borderline tumors [59] should be further explored.

\subsubsection{Pro-Tumorigenic Role of $\beta i g-H 3$ in Ovarian Cancer}

In our recent study we have demonstrated that $\beta$ ig-H3 induces both motility and invasion of OVCAR-5 and SKOV-3 cells, but does not affect motility or invasion of OVCAR-3 ovarian cancer cells that are known to be less metastatic [61]. We have also shown that $\beta$ ig-H3 promotes attachment of OVCAR-5, SKOV-3, and OVCAR-3 to LP-9 peritoneal cells [61]. These findings suggest that Big-H3 may function in multiple ways to promote ovarian cancer metastasis and that the effects on motility may be independent of those on adhesion.

In our study, the effects of $\beta$ ig-H3 on OVCAR-5 cells were independent of the $\beta$ ig-H3 RGD integrin binding motif (amino acids 642-644), since treatment with ERGDEL peptide did not block the ability of $\beta$ ig-H3 to promote ovarian cancer cell motility, invasion, or adhesion to peritoneal cells. Our data suggests that $\beta$ ig-H3 activity on OVCAR-5 cells is mediated by other sites in the $\beta$ ig-H3 molecule other than the RGD motif, which may include the EPDIM and NKDIL motifs as well as the sequence spanning the YH18 motif.

\subsubsection{Big-H3 Processing by Ovarian Cancer Peritoneal Interactions}

We have shown that $\beta$ ig-H3 cleavage in the ovarian cancer-peritoneal cell co-culture occurs between amino acid residues 27-76 in the $N$-terminus and amino acid residues 626-657 in the $C$-terminal domain [61]. Although the functional role of the $N$-terminal $\beta$ ig-H3 domain has not been well studied, the $C$-terminus has several integrin binding motifs including the RGD, YH18, and EPDIM sequences. $\beta$ ig-H3 fragments including the EPDIM and the RGD motif, have recently been shown to promote apoptosis of osteosarcoma cells [57]. A truncated Big-H3 lacking the EPDIM but not the RGD motif failed to induce apoptosis in this cell type [57].

Whilst it is not known whether the $C$-terminal processed $\beta$ ig- $\mathrm{H} 3$ in the secretome of the ovarian cancer-peritoneal co-culture retains its RGD sequence at amino acid 642-644, the EPDIM motif at amino acid 617-621 is maintained in the $C$-terminal processed $\beta$ ig-H3. Crystal structure of the FAS-1 domains (Drosphilia TGFBI/Big-H3 homologue) has identified a novel fold domain consisting of a seven-stranded $\beta$-wedge and a number of $\alpha$-helices in the 3 rd and 4 th FAS-1 domains [88]. The EPDIM motif maps to a conserved kink in the $\beta 6$ strand of the fourth $\beta$ ig-H3 FAS- 1 domain and is predicted to be buried within the domain protein core [88]. $\beta$ ig-H3 processing by proteases, including plasmin between amino acids 626-655 may expose the EPDIM motif (amino acids 617-621) site for integrin interactions and may promote the integrin binding activity on the surface of the peritoneum [89-91] with ovarian cancer cells [92,93] and increase ovarian cancer metastatic behavior.

Interestingly, $\beta$ ig-H3 processing was only observed when ovarian cancer cells and peritoneal cells were in direct physical contact in culture, or when the cells shared the same growth media in the 
co-culture system [61]. ßig-H3 processing did not occur when conditioned media from peritoneal cells was added to cultured ovarian cancer cell lines, or when conditioned media from ovarian cancer cells was added to the cultured peritoneal cells. This indicates that $\beta$ ig- $\mathrm{H} 3$ processing is not mediated by a simple up-regulation of ovarian cancer cell derived proteases but requires multiple levels of cross-talk between both ovarian cancer and peritoneal cells. A similar paracrine effect was previously reported for endometrial cancer epithelium-stroma cell co-cultures, where hepatic growth factor secreted by the stromal cells acted on the endometrial cancer cells by inducing the cleavage of MMPs pro-forms to mature active forms [94]. Our findings suggest, however, that cleavage of $\beta$ ig-H3 in the ovarian cancer and peritoneal cell co-culture is not MMP mediated as the broad spectrum MMP inhibitor, GM6001, failed to inhibit $\beta$ ig-H3 processing. Instead, we found that the protease plasmin cleaved $\beta$ ig-H3 in the same region as observed in the ovarian cancer-peritoneal cell co-culture and that this could be inhibited by a cocktail of protease inhibitors, including serine protease inhibitors. We demonstrated that plasmin activity was increased in the conditioned medium of co-cultured OVCAR-5 and LP-9 cells, whilst no plasmin activity could be detected in the conditioned medium collected from those cells cultured alone [61]. These findings add to our understanding of the interaction between ovarian cancer and peritoneal cells and suggest that increased plasmin production and $\beta$ ig- $\mathrm{H} 3$ cleavage may be early events in the process of ovarian cancer metastasis.

\subsubsection{4. $\beta$ ig- $\mathrm{H} 3$ as a Predictor of Therapy Response}

The level of $\beta$ ig-H3 in ovarian cancer tissue has been shown to be a predictive marker of response to treatment with the aromatase inhibitor letrozole [95] and the chemotherapeutic drug paclitaxel [86]. The loss of $\beta$ ig-H3 induces a specific resistance to paclitaxel and is associated with mitotic spindle abnormalities in ovarian cancer cells [86]. Paclitaxel-resistant cells treated with recombinant $\beta$ ig-H3 protein show integrin-dependent restoration of paclitaxel sensitivity via FAK- and Rho-dependent stabilization of microtubules [86]. More recent studies have also shown that the suppression of $\beta 3$ integrin and $\beta \mathrm{ig}-\mathrm{H} 3$ increase the resistance of SKOV3 to paclitaxel [87]. A strong association between elevated $\beta$ ig- $\mathrm{H} 3$ expression and the response to chemotherapy has also been identified in lung cancer patients [96]. Lung cancer cells over-expressing $\beta$ ig-H3 displayed increased sensitivity to etoposide, paclitaxel, cisplatin, and gemcitabine. $\beta$ ig-H3-mediated induction of apoptosis occurred through its binding to $\alpha \mathrm{v} \beta 3$ integrin by proteolytic fragments of $\beta$ ig- $\mathrm{H} 3$ and not full length protein [96]. Together these data show that $\beta$ ig-H3 is also a potential therapeutic to improve response to chemotherapy in ovarian cancer patients.

\section{Conclusions}

Studies over the last 5 years have increased our understanding of the role of $\beta$ ig- $\mathrm{H} 3$ in cancer. However, there is conflicting data in the literature reporting that $\beta \mathrm{ig}-\mathrm{H} 3$ can have a tumor suppressive as well as a tumor promoting role in different cancer cells. These opposing effects of $\beta$ ig-H3 have been identified in several different laboratories and are unlikely to be due to biased observations. $\beta$ ig-H3 expression and function in cancer cells appears to be cell type specific and is affected by ßig-H3 concentration but also by processing events by protease enzymes which can liberate integrin binding sites. As truncated forms of $\beta$ ig-H3 have been well documented to have differing functions it is likely 
that alterations in $\beta$ ig- $\mathrm{H} 3$ processing in different cell types is an important factor contributing to the disparate findings in literature. Our findings highlight the need for amino acid sequencing to confirm the presence of full length or truncated forms of $\beta$ ig-H3 [61]. The findings that siRNA TGFBI knockdown increased melanoma cell growth and invasion in vitro but greatly impaired subcutaneous tumor growth in nude mice highlights the importance of the tumor microenvironment for Big-H3 function [76]. Whether $\beta$ ig-H3 functions as a tumor suppressor or tumor promotor may also be dependent on interactions between other ECM proteins and specific integrin receptors present in the tumor microenvironment.

Our research demonstrating that $\beta$ ig-H3 is down-regulated in ovarian cancer and promotes ovarian cancer cell death supports a tumor suppressor role. However $\beta$ ig- $\mathrm{H} 3$ is abundantly expressed by peritoneal cells and can promote metastatic behavior of ovarian cancer cells. Consequently, in ovarian cancer, ßig-H3 may act as a "double-edged sword". The loss of $\beta$ ig-H3 promotes ovarian tumorigenesis, microtubule and chromosome instability and a more chemoresistant phenotype, however in the peritoneal microenvironment; $\beta$ ig-H3 produced by the peritoneal cells aids the metastatic process. Our ovarian cancer studies to date indicate that $\beta$ ig-H3 is a potential therapeutic target to inhibit ovarian cancer metastasis to the peritoneum. Further studies investigating therapeutic strategies to block $\beta$ ig-H3 action in ovarian cancer are therefore warranted. $\beta$ ig-H3 derived peptides could be used to both block ovarian cancer metastasis and enhance chemotherapy response.

\section{Acknowledgments}

This work was supported by the Cancer Council of South Australia \& South Australian Health and Medical Research Institute (Senior Cancer Fellowship to CR), and the Ovarian Cancer Research Foundation, Australia.

\section{References}

1. Skonier, J.; Neubauer, M.; Madisen, L.; Bennett, K.; Plowman, G.D.; Purchio, A.F. cDNA cloning and sequence analysis of beta ig-h3, a novel gene induced in a human adenocarcinoma cell line after treatment with transforming growth factor-beta. DNA Cell Biol. 1992, 11, 511-522.

2. Becker, J.; Erdlenbruch, B.; Noskova, I.; Schramm, A.; Aumailley, M.; Schorderet, D.F.; Schweigerer, L. Keratoepithelin suppresses the progression of experimental human neuroblastomas. Cancer Res. 2006, 66, 5314-5321.

3. Hashimoto, K.; Noshiro, M.; Ohno, S.; Kawamoto, T.; Satakeda, H.; Akagawa, Y.; Nakashima, K.; Okimura, A.; Ishida, H.; Okamoto, T.; et al. Characterization of a cartilage-derived 66-kDa protein (RGD-CAP/beta ig-h3) that binds to collagen. Biochim. Biophys. Acta 1997, 1355, 303-314.

4. Gibson, M.A.; Kumaratilake, J.S.; Cleary, E.G. Immunohistochemical and ultrastructural localization of MP78/70 (betaig-h3) in extracellular matrix of developing and mature bovine tissues. J. Histochem. Cytochem. 1997, 45, 1683-1696.

5. Liu, C.; Li, B.; Cheng, Y.; Lin, J.; Hao, J.; Zhang, S.; Mitchel, R.E.; Sun, D.; Ni, J.; Zhao, L.; Gao, F.; Cai, J. MiR-21 plays an important role in radiation induced carcinogenesis in BALB/c mice by directly targeting the tumor suppressor gene Big-h3. Int. J. Biol. Sci. 2011, 7, 347-363. 
6. Sasaki, H.; Kobayashi, Y.; Nakashima, Y.; Moriyama, S.; Yukiue, H.; Kaji, M.; Kiriyama, M.; Fukai, I.; Yamakawa, Y.; Fujii, Y. Beta IGH3, a TGF-beta inducible gene, is overexpressed in lung cancer. Jpn. J. Clin. Oncol. 2002, 32, 85-89.

7. Rawe, I.M.; Zhan, Q.; Burrows, R.; Bennett, K.; Cintron, C. Beta-ig. Molecular cloning and in situ hybridization in corneal tissues. Invest. Ophthalmol. Vis. Sci. 1997, 38, 893-900.

8. Gibson, M.A.; Kumaratilake, J.S.; Cleary, E.G. The protein components of the 12-nanometer microfibrils of elastic and nonelastic tissues. J. Biol. Chem. 1989, 264, 4590-4598.

9. Schorderet, D.F.; Menasche, M.; Morand, S.; Bonnel, S.; Buchillier, V.; Marchant, D.; Auderset, K.; Bonny, C.; Abitbol, M.; Munier, F.L. Genomic characterization and embryonic expression of the mouse Bigh3 (Tgfbi) gene. Biochem. Biophys. Res. Commun. 2000, 274, 267-274.

10. LeBaron, R.G.; Bezverkov, K.I.; Zimber, M.P.; Pavelec, R.; Skonier, J.; Purchio, A.F. Beta IG-H3, a novel secretory protein inducible by transforming growth factor-beta, is present in normal skin and promotes the adhesion and spreading of dermal fibroblasts in vitro. J. Invest. Dermatol. 1995, 104, 844-849.

11. Kim, J.E.; Kim, S.J.; Lee, B.H.; Park, R.W.; Kim, K.S.; Kim, I.S. Identification of motifs for cell adhesion within the repeated domains of transforming growth factor-beta-induced gene, betaig-h3. J. Biol. Chem. 2000, 275, 30907-30915.

12. Thapa, N.; Lee, B.H.; Kim, I.S. TGFBIp/betaig-h3 protein: A versatile matrix molecule induced by TGF-beta. Int. J. Biochem. Cell Biol. 2007, 39, 2183-2194.

13. Uekita, T.; Kim, Y.J.; Yamanouchi, K.; Tojo, H.; Tachi, C. Dynamics of betaig-h3 mRNA expression during pregnancy in the uterus and the placenta of the mouse: A possible regulatory factor for trophoblastic invasion. J. Reprod. Dev. 2003, 49, 243-252.

14. Carson, D.D.; Lagow, E.; Thathiah, A.; Al-Shami, R.; Farach-Carson, M.C.; Vernon, M.; Yuan, L.; Fritz, M.A.; Lessey, B. Changes in gene expression during the early to mid-luteal (receptive phase) transition in human endometrium detected by high-density microarray screening. Mol. Hum. Reprod. 2002, 8, 871-879.

15. Gratchev, A.; Guillot, P.; Hakiy, N.; Politz, O.; Orfanos, C.E.; Schledzewski, K.; Goerdt, S. Alternatively activated macrophages differentially express fibronectin and its splice variants and the extracellular matrix protein betaIG-H3. Scand. J. Immunol. 2001, 53, 386-392.

16. Yun, S.J.; Kim, M.O.; Kim, S.O.; Park, J.; Kwon, Y.K.; Kim, I.S.; Lee, E.H. Induction of TGF-beta-inducible gene-h3 (betaig-h3) by TGF-beta1 in astrocytes: Implications for astrocyte response to brain injury. Brain Res. Mol. Brain Res. 2002, 107, 57-64.

17. Dokmanovic, M.; Chang, B.D.; Fang, J.; Roninson, I.B. Retinoid-induced growth arrest of breast carcinoma cells involves co-activation of multiple growth-inhibitory genes. Cancer Biol. Ther. 2002, 1, 24-27.

18. Nam, E.J.; Sa, K.H.; You, D.W.; Cho, J.H.; Seo, J.S.; Han, S.W.; Park, J.Y.; Kim, S.I.; Kyung, H.S.; Kim, I.S.; et al. Up-regulated transforming growth factor beta-inducible gene h3 in rheumatoid arthritis mediates adhesion and migration of synoviocytes through $\alpha \mathrm{v} \beta 3$ integrin: Regulation by cytokines. Arthritis Rheum. 2006, 54, 2734-2744. 
19. Lee, S.H.; Kim, E.J.; Suk, K.; Kim, I.S.; Lee, W.H. TL1A induces the expression of TGF-beta-inducible gene h3 (ßig-h3) through PKC, PI3K, and ERK in THP-1 cells. Cell. Immunol. 2010, 266, 61-66.

20. Shin, S.H.; Kim, J.; Heo, S.C.; Kwon, Y.W.; Kim, Y.M.; Kim, I.S.; Lee, T.G.; Kim, J.H. Proteomic identification of betaig-h3 as a lysophosphatidic acid-induced secreted protein of human mesenchymal stem cells: Paracrine activation of A549 lung adenocarcinoma cells by betaig-h3. Mol. Cell. Proteomics 2012, 11, doi:10.1074/mcp.M111.012385.

21. Lee, B.H.; Bae, J.S.; Park, R.W.; Kim, J.E.; Park, J.Y.; Kim, I.S. Betaig-h3 triggers signaling pathways mediating adhesion and migration of vascular smooth muscle cells through $\alpha \mathrm{v} \beta 5$ integrin. Exp. Mol. Med. 2006, 38, 153-161.

22. O’Brien, E.R.; Bennett, K.L.; Garvin, M.R.; Zderic, T.W.; Hinohara, T.; Simpson, J.B.; Kimura, T.; Nobuyoshi, M.; Mizgala, H.; Purchio, A.; et al. Beta ig-h3, a transforming growth factor-beta-inducible gene, is overexpressed in atherosclerotic and restenotic human vascular lesions. Arterioscler. Thromb. Vasc. Biol. 1996, 16, 576-584.

23. Dieudonne, S.C.; Kerr, J.M.; Xu, T.; Sommer, B.; DeRubeis, A.R.; Kuznetsov, S.A.; Kim, I.S.; Gehron Robey, P.; Young, M.F. Differential display of human marrow stromal cells reveals unique mRNA expression patterns in response to dexamethasone. J. Cell. Biochem. 1999, 76, 231-243.

24. Monticone, M.; Liu, Y.; Tonachini, L.; Mastrogiacomo, M.; Parodi, S.; Quarto, R.; Cancedda, R.; Castagnola, P. Gene expression profile of human bone marrow stromal cells determined by restriction fragment differential display analysis. J. Cell. Biochem. 2004, 92, 733-744.

25. Thapa, N.; Kang, K.B.; Kim, I.S. Beta ig-h3 mediates osteoblast adhesion and inhibits differentiation. Bone 2005, 36, 232-242.

26. Billings, P.C.; Whitbeck, J.C.; Adams, C.S.; Abrams, W.R.; Cohen, A.J.; Engelsberg, B.N.; Howard, P.S.; Rosenbloom, J. The transforming growth factor-beta-inducible matrix protein (beta)ig-h3 interacts with fibronectin. J. Biol. Chem. 2002, 277, 28003-28009.

27. Hanssen, E.; Reinboth, B.; Gibson, M.A. Covalent and non-covalent interactions of betaig-h3 with collagen VI. Beta ig-h3 is covalently attached to the amino-terminal region of collagen VI in tissue microfibrils. J. Biol. Chem. 2003, 278, 24334-24341.

28. Reinboth, B.; Thomas, J.; Hanssen, E.; Gibson, M.A. Beta ig-h3 interacts directly with biglycan and decorin, promotes collagen VI aggregation, and participates in ternary complexing with these macromolecules. J. Biol. Chem. 2006, 281, 7816-7824.

29. Kim, J.E.; Jeong, H.W.; Nam, J.O.; Lee, B.H.; Choi, J.Y.; Park, R.W.; Park, J.Y.; Kim, I.S. Identification of motifs in the fasciclin domains of the transforming growth factor-beta-induced matrix protein betaig-h3 that interact with the $\alpha v \beta 5$ integrin. J. Biol. Chem. 2002, 277, 46159-46165.

30. Ohno, S.; Noshiro, M.; Makihira, S.; Kawamoto, T.; Shen, M.; Yan, W.; Kawashima-Ohya, Y.; Fujimoto, K.; Tanne, K.; Kato, Y. RGD-CAP ( $\beta$ ig-h3) enhances the spreading of chondrocytes and fibroblasts via integrin $\alpha 1 \beta 1$. Biochim. Biophys. Acta 1999, 1451, 196-205.

31. Bae, J.S.; Lee, S.H.; Kim, J.E.; Choi, J.Y.; Park, R.W.; Yong Park, J.; Park, H.S.; Sohn, Y.S.; Lee, D.S.; Bae Lee, E.; et al. Betaig-h3 supports keratinocyte adhesion, migration, and proliferation through $\alpha 3 \beta 1$ integrin. Biochem. Biophys. Res. Commun. 2002, 294, 940-948. 
32. Jeong, H.W.; Kim, I.S. TGF-betal enhances betaig-h3-mediated keratinocyte cell migration through the $\alpha 3 \beta 1$ integrin and PI3K. J. Cell. Biochem. 2004, 92, 770-780.

33. Kim, H.J.; Kim, I.S. Transforming growth factor-beta-induced gene product, as a novel ligand of integrin $\alpha \mathrm{M} \beta 2$, promotes monocytes adhesion, migration and chemotaxis. Int. J. Biochem. Cell Biol. 2008, 40, 991-1004.

34. Park, S.J.; Park, S.; Ahn, H.C.; Kim, I.S.; Lee, B.J. Conformational resemblance between the structures of integrin-activating pentapetides derived from betaig-h3 and RGD peptide analogues in a membrane environment. Peptides 2004, 25, 199-205.

35. Nam, J.O.; Kim, J.E.; Jeong, H.W.; Lee, S.J.; Lee, B.H.; Choi, J.Y.; Park, R.W.; Park, J.Y.; Kim, I.S. Identification of the $\alpha v \beta 3$ integrin-interacting motif of betaig-h3 and its anti-angiogenic effect. J. Biol. Chem. 2003, 278, 25902-25909.

36. Li, C.; Lim, S.W.; Choi, B.S.; Lee, S.H.; Cha, J.H.; Kim, I.S.; Kim, J.; Yang, C.W. Inhibitory effect of pravastatin on transforming growth factor betal-inducible gene h3 expression in a rat model of chronic cyclosporine nephropathy. Am. J. Nephrol. 2005, 25, 611-620.

37. Lee, S.H.; Bae, J.S.; Park, S.H.; Lee, B.H.; Park, R.W.; Choi, J.Y.; Park, J.Y.; Ha, S.W.; Kim, Y.L.; Kwon, T.H.; et al. Expression of TGF-beta-induced matrix protein betaig-h3 is up-regulated in the diabetic rat kidney and human proximal tubular epithelial cells treated with high glucose. Kidney Int. 2003, 64, 1012-1021.

38. Cha, D.R.; Kim, I.S.; Kang, Y.S.; Han, S.Y.; Han, K.H.; Shin, C.; Ji, Y.H.; Kim, N.H. Urinary concentration of transforming growth factor-beta-inducible gene-h3(beta ig-h3) in patients with Type 2 diabetes mellitus. Diabet. Med. 2005, 22, 14-20.

39. Ha, S.W.; Kim, H.J.; Bae, J.S.; Jeong, G.H.; Chung, S.C.; Kim, J.G.; Park, S.H.; Kim, Y.L.; Kam, S.; Kim, I.S.; et al. Elevation of urinary betaig-h3, transforming growth factor-beta-induced protein in patients with type 2 diabetes and nephropathy. Diabetes Res. Clin. Pract. 2004, 65, 167-173.

40. Han, J.H.; Ha, S.W.; Lee, I.K.; Kim, B.W.; Kim, J.G. High glucose-induced apoptosis in bovine retinal pericytes is associated with transforming growth factor beta and betaIG-H3: BetaIG-H3 induces apoptosis in retinal pericytes by releasing Arg-Gly-Asp peptides. Clin. Exp. Ophthalmol. 2010, 38, 620-628.

41. Wang, Y.; Zhao, S.; Loyd, S.; Groome, L.J. Increased urinary excretion of nephrin, podocalyxin, and betaig-h3 in women with preeclampsia. Am. J. Physiol. Renal. Physiol. 2012, 302, F1084-F1089.

42. Hedegaard, C.J.; Thogersen, I.B.; Enghild, J.J.; Klintworth, G.K.; Moller-Pedersen, T. Transforming growth factor beta induced protein accumulation in granular corneal dystrophy type III (Reis-Bucklers dystrophy). Identification by mass spectrometry in 15 year old two-dimensional protein gels. Mol. Vis. 2003, 9, 355-359.

43. Konishi, M.; Yamada, M.; Nakamura, Y.; Mashima, Y. Immunohistology of kerato-epithelin in corneal stromal dystrophies associated with R124 mutations of the BIGH3 gene. Curr. Eye Res. 2000, 21, 891-896.

44. Korvatska, E.; Munier, F.L.; Chaubert, P.; Wang, M.X.; Mashima, Y.; Yamada, M.; Uffer, S.; Zografos, L.; Schorderet, D.F. On the role of kerato-epithelin in the pathogenesis of 5q31-linked corneal dystrophies. Invest. Ophthalmol. Vis. Sci. 1999, 40, 2213-2219. 
45. Streeten, B.W.; Qi, Y.; Klintworth, G.K.; Eagle, R.C., Jr.; Strauss, J.A.; Bennett, K. Immunolocalization of beta ig-h3 protein in 5q31-linked corneal dystrophies and normal corneas. Arch. Ophthalmol. 1999, 117, 67-75.

46. Kannabiran, C.; Klintworth, G.K. TGFBI gene mutations in corneal dystrophies. Hum. Mutat. 2006, 27, 615-625.

47. Shao, G.; Berenguer, J.; Borczuk, A.C.; Powell, C.A.; Hei, T.K.; Zhao, Y. Epigenetic inactivation of Betaig-h3 gene in human cancer cells. Cancer Res. 2006, 66, 4566-4573.

48. Skonier, J.; Bennett, K.; Rothwell, V.; Kosowski, S.; Plowman, G.; Wallace, P.; Edelhoff, S.; Disteche, C.; Neubauer, M.; Marquardt, H.; et al. Beta ig-h3: A transforming growth factor-beta-responsive gene encoding a secreted protein that inhibits cell attachment in vitro and suppresses the growth of CHO cells in nude mice. DNA Cell Biol. 1994, 13, 571-584.

49. Kim, J.E.; Kim, S.J.; Jeong, H.W.; Lee, B.H.; Choi, J.Y.; Park, R.W.; Park, J.Y.; Kim, I.S. RGD peptides released from beta ig-h3, a TGF-beta-induced cell-adhesive molecule, mediate apoptosis. Oncogene 2003, 22, 2045-2053.

50. Zhao, Y.L.; Piao, C.Q.; Hei, T.K. Overexpression of Betaig-h3 gene downregulates integrin $\alpha 5 \beta 1$ and suppresses tumorigenicity in radiation-induced tumorigenic human bronchial epithelial cells. Br. J. Cancer 2002, 86, 1923-1928.

51. Zhao, Y.L.; Piao, C.Q.; Hei, T.K. Downregulation of Betaig-h3 gene is causally linked to tumorigenic phenotype in asbestos treated immortalized human bronchial epithelial cells. Oncogene 2002, 21, 7471-7477.

52. Zhao, Y.; Shao, G.; Piao, C.Q.; Berenguer, J.; Hei, T.K. Down-regulation of Betaig-h3 gene is involved in the tumorigenesis in human bronchial epithelial cells induced by heavy-ion radiation. Radiat. Res. 2004, 162, 655-659.

53. Zhao, Y.; El-Gabry, M.; Hei, T.K. Loss of Betaig-h3 protein is frequent in primary lung carcinoma and related to tumorigenic phenotype in lung cancer cells. Mol. Carcinog. 2006, 45, 84-92.

54. Wen, G.; Partridge, M.A.; Li, B.; Hong, M.; Liao, W.; Cheng, S.K.; Zhao, Y.; Calaf, G.M.; Liu, T.; Zhou, J.; et al. TGFBI expression reduces in vitro and in vivo metastatic potential of lung and breast tumor cells. Cancer Lett. 2011, 308, 23-32.

55. Wen, G.; Hong, M.; Li, B.; Liao, W.; Cheng, S.K.; Hu, B.; Calaf, G.M.; Lu, P.; Partridge, M.A.; Tong, J.; et al. Transforming growth factor-beta-induced protein (TGFBI) suppresses mesothelioma progression through the Akt/mTOR pathway. Int. J. Oncol. 2011, 39, 1001-1009.

56. Becker, J.; Volland, S.; Noskova, I.; Schramm, A.; Schweigerer, L.L.; Wilting, J. Keratoepithelin reverts the suppression of tissue factor pathway inhibitor 2 by MYCN in human neuroblastoma: A mechanism to inhibit invasion. Int. J. Oncol. 2008, 32, 235-240.

57. Zamilpa, R.; Rupaimoole, R.; Phelix, C.F.; Somaraki-Cormier, M.; Haskins, W.; Asmis, R.; Lebaron, R.G. $C$-terminal fragment of transforming growth factor beta-induced protein (TGFBIp) is required for apoptosis in human osteosarcoma cells. Matrix Biol. 2009, 28, 347-357.

58. Zhang, Y.; Wen, G.; Shao, G.; Wang, C.; Lin, C.; Fang, H.; Balajee, A.S.; Bhagat, G.; Hei, T.K.; Zhao, Y. TGFBI deficiency predisposes mice to spontaneous tumor development. Cancer Res. 2009, 69, 37-44. 
59. Kang, S.; Dong, S.M.; Park, N.H. Frequent promoter hypermethylation of TGFBI in epithelial ovarian cancer. Gynecol. Oncol. 2010, 118, 58-63.

60. Wang, N.; Zhang, H.; Yao, Q.; Wang, Y.; Dai, S.; Yang, X. TGFBI promoter hypermethylation correlating with paclitaxel chemoresistance in ovarian cancer. J. Exp. Clin. Cancer Res. 2012, 31, doi:10.1186/1756-9966-31-6.

61. Ween, M.P.; Lokman, N.A.; Hoffmann, P.; Rodgers, R.J.; Ricciardelli, C.; Oehler, M.K. Transforming growth factor-beta-induced protein secreted by peritoneal cells increases the metastatic potential of ovarian cancer cells. Int. J. Cancer 2011, 128, 1570-1584.

62. Calaf, G.M.; Echiburu-Chau, C.; Zhao, Y.L.; Hei, T.K. BigH3 protein expression as a marker for breast cancer. Int. J. Mol. Med. 2008, 21, 561-568.

63. Ivanov, S.V.; Ivanova, A.V.; Salnikow, K.; Timofeeva, O.; Subramaniam, M.; Lerman, M.I. Two novel VHL targets, TGFBI (BIGH3) and its transactivator KLF10, are up-regulated in renal clear cell carcinoma and other tumors. Biochem. Biophys. Res. Commun. 2008, 370, 536-540.

64. Yamanaka, M.; Kimura, F.; Kagata, Y.; Kondoh, N.; Asano, T.; Yamamoto, M.; Hayakawa, M. $\mathrm{BIGH} 3$ is overexpressed in clear cell renal cell carcinoma. Oncol. Rep. 2008, 19, 865-874.

65. Hourihan, R.N.; O’Sullivan, G.C.; Morgan, J.G. Transcriptional gene expression profiles of oesophageal adenocarcinoma and normal oesophageal tissues. Anticancer Res. 2003, 23, 161-165.

66. Kitahara, O.; Furukawa, Y.; Tanaka, T.; Kihara, C.; Ono, K.; Yanagawa, R.; Nita, M.E.; Takagi, T.; Nakamura, Y.; Tsunoda, T. Alterations of gene expression during colorectal carcinogenesis revealed by cDNA microarrays after laser-capture microdissection of tumor tissues and normal epithelia. Cancer Res. 2001, 61, 3544-3549.

67. Golembieski, W.A.; Rempel, S.A. cDNA array analysis of SPARC-modulated changes in glioma gene expression. J. Neurooncol. 2002, 60, 213-226.

68. Schneider, D.; Kleeff, J.; Berberat, P.O.; Zhu, Z.; Korc, M.; Friess, H.; Buchler, M.W. Induction and expression of betaig-h3 in pancreatic cancer cells. Biochim. Biophys. Acta 2002, 1588, 1-6.

69. Aitkenhead, M.; Wang, S.J.; Nakatsu, M.N.; Mestas, J.; Heard, C.; Hughes, C.C. Identification of endothelial cell genes expressed in an in vitro model of angiogenesis: Induction of ESM-1, (beta)ig-h3, and NrCAM. Microvasc. Res. 2002, 63, 159-171.

70. Zajchowski, D.A.; Bartholdi, M.F.; Gong, Y.; Webster, L.; Liu, H.L.; Munishkin, A.; Beauheim, C.; Harvey, S.; Ethier, S.P.; Johnson, P.H. Identification of gene expression profiles that predict the aggressive behavior of breast cancer cells. Cancer Res. 2001, 61, 5168-5178.

71. Ma, C.; Rong, Y.; Radiloff, D.R.; Datto, M.B.; Centeno, B.; Bao, S.; Cheng, A.W.; Lin, F.; Jiang, S.; Yeatman, T.J.; et al. Extracellular matrix protein $\beta$ ig-h3/TGFBI promotes metastasis of colon cancer by enhancing cell extravasation. Genes Dev. 2008, 22, 308-321.

72. Kim, M.O.; Yun, S.J.; Kim, I.S.; Sohn, S.; Lee, E.H. Transforming growth factor-beta-inducible gene-h3 ( $\beta$ ig-h3) promotes cell adhesion of human astrocytoma cells in vitro: Implication of $\alpha 6 \beta 4$ integrin. Neurosci. Lett. 2003, 336, 93-96.

73. Tang, J.; Zhou, H.W.; Jiang, J.L.; Yang, X.M.; Li, Y.; Zhang, H.X.; Chen, Z.N.; Guo, W.P. BetaIg-h3 is involved in the HAb18G/CD147-mediated metastasis process in human hepatoma cells. Exp. Biol. Med. 2007, 232, 344-352. 
74. Tang, J.; Wu, Y.M.; Zhao, P.; Jiang, J.L.; Chen, Z.N. Betaig-h3 interacts with $\alpha 3 \beta 1$ integrin to promote adhesion and migration of human hepatoma cells. Exp. Biol. Med. 2009, 234, 35-39.

75. Irigoyen, M.; Anso, E.; Salvo, E.; de las Herrerias, J.D.; Martinez-Irujo, J.J.; Rouzaut, A. TGFbeta-induced protein mediates lymphatic endothelial cell adhesion to the extracellular matrix under low oxygen conditions. Cell. Mol. Life Sci. 2008, 65, 2244-2255.

76. Nummela, P.; Lammi, J.; Soikkeli, J.; Saksela, O.; Laakkonen, P.; Holtta, E. Transforming growth factor beta-induced (TGFBI) is an anti-adhesive protein regulating the invasive growth of melanoma cells. Am. J. Pathol. 2012, 180, 1663-1674.

77. Guo, Y.S.; Tang, J.; Chen, B.; Huang, W.; Li, Y.; Cui, H.Y.; Zhang, X.; Wang, S.J.; Chen, Z.N.; Jiang, J.L. Betaig-h3 regulates store-operated $\mathrm{Ca} 2+$ entry and promotes the invasion of human hepatocellular carcinoma cells. Cell Biol. Int. 2011, 35, 811-817.

78. Hu, Y.C.; Lam, K.Y.; Law, S.; Wong, J.; Srivastava, G. Profiling of differentially expressed cancer-related genes in esophageal squamous cell carcinoma (ESCC) using human cancer cDNA arrays: Overexpression of oncogene MET correlates with tumor differentiation in ESCC. Clin. Cancer Res. 2001, 7, 3519-3525.

79. Wong, F.H.; Huang, C.Y.; Su, L.J.; Wu, Y.C.; Lin, Y.S.; Hsia, J.Y.; Tsai, H.T.; Lee, S.A.; Lin, C.H.; Tzeng, C.H.; et al. Combination of microarray profiling and protein-protein interaction databases delineates the minimal discriminators as a metastasis network for esophageal squamous cell carcinoma. Int. J. Oncol. 2009, 34, 117-128.

80. Turtoi, A.; Musmeci, D.; Wang, Y.; Dumont, B.; Somja, J.; Bevilacqua, G.; de Pauw, E.; Delvenne, P.; Castronovo, V. Identification of novel accessible proteins bearing diagnostic and therapeutic potential in human pancreatic ductal adenocarcinoma. J. Proteome Res. 2011, 10, 4302-4313.

81. Tomioka, H.; Morita, K.; Hasegawa, S.; Omura, K. Gene expression analysis by cDNA microarray in oral squamous cell carcinoma. J. Oral Pathol. Med. 2006, 35, 206-211.

82. Lin, B.; Madan, A.; Yoon, J.G.; Fang, X.; Yan, X.; Kim, T.K.; Hwang, D.; Hood, L.; Foltz, G. Massively parallel signature sequencing and bioinformatics analysis identifies up-regulation of TGFBI and SOX4 in human glioblastoma. PLoS One 2010, 5, e10210.

83. Ma, J.; Cui, W.; He, S.M.; Duan, Y.H.; Heng, L.J.; Wang, L.; Gao, G.D. Human U87 astrocytoma cell invasion induced by interaction of $\beta$ ig-h3 with integrin $\alpha 5 \beta 1$ involves calpain-2. PLoS One 2012, 7, e37297.

84. Buckhaults, P.; Rago, C.; St Croix, B.; Romans, K.E.; Saha, S.; Zhang, L.; Vogelstein, B.; Kinzler, K.W. Secreted and cell surface genes expressed in benign and malignant colorectal tumors. Cancer Res. 2001, 61, 6996-7001.

85. Ohno, Y.; Izumi, M.; Tachibana, M.; Kawamura, T.; Yoshioka, K.; Aoyagi, T.; Ohori, M.; Namiki, K.; Sakamoto, N.; Nakagami, Y.; et al. Characterization and gene expression analysis of novel matched primary and metastatic renal cell carcinoma cell lines. Oncol. Rep. 2008, 20, 501-509.

86. Ahmed, A.A.; Mills, A.D.; Ibrahim, A.E.; Temple, J.; Blenkiron, C.; Vias, M.; Massie, C.E.; Iyer, N.G.; McGeoch, A.; Crawford, R.; et al. The extracellular matrix protein TGFBI induces microtubule stabilization and sensitizes ovarian cancers to paclitaxel. Cancer Cell 2007, $12,514-527$. 
87. Tumbarello, D.A.; Temple, J.; Brenton, J.D. Beta3 integrin modulates transforming growth factor beta induced (TGFBI) function and paclitaxel response in ovarian cancer cells. Mol. Cancer 2012, 11, doi:10.1186/1476-4598-11-36.

88. Clout, N.J.; Hohenester, E. A model of FAS1 domain 4 of the corneal protein beta(ig)-h3 gives a clearer view on corneal dystrophies. Mol. Vis. 2003, 9, 440-448.

89. Gardner, M.J.; Jones, L.M.; Catterall, J.B.; Turner, G.A. Expression of cell adhesion molecules on ovarian tumour cell lines and mesothelial cells, in relation to ovarian cancer metastasis. Cancer Lett. 1995, 91, 229-234.

90. Witz, C.A.; Takahashi, A.; Montoya-Rodriguez, I.A.; Cho, S.; Schenken, R.S. Expression of the $\alpha 2 \beta 1$ and $\alpha 3 \beta 1$ integrins at the surface of mesothelial cells: A potential attachment site of endometrial cells. Fertil. Steril. 2000, 74, 579-584.

91. Heyman, L.; Kellouche, S.; Fernandes, J.; Dutoit, S.; Poulain, L.; Carreiras, F. Vitronectin and its receptors partly mediate adhesion of ovarian cancer cells to peritoneal mesothelium in vitro. Tumour Biol. 2008, 29, 231-244.

92. Cannistra, S.A.; Abu-Jawdeh, G.; Niloff, J.; Strobel, T.; Swanson, L.; Andersen, J.; Ottensmeier, C. CD44 variant expression is a common feature of epithelial ovarian cancer: Lack of association with standard prognostic factors. J. Clin. Oncol. 1995, 13, 1912-1921.

93. Strobel, T.; Cannistra, S.A. Beta1-integrins partly mediate binding of ovarian cancer cells to peritoneal mesothelium in vitro. Gynecol. Oncol. 1999, 73, 362-367.

94. Park, Y.H.; Ryu, H.S.; Choi, D.S.; Chang, K.H.; Park, D.W.; Min, C.K. Effects of hepatocyte growth factor on the expression of matrix metalloproteinases and their tissue inhibitors during the endometrial cancer invasion in a three-dimensional coculture. Int. J. Gynecol. Cancer 2003, 13, $53-60$.

95. Walker, G.; MacLeod, K.; Williams, A.R.; Cameron, D.A.; Smyth, J.F.; Langdon, S.P. Estrogen-regulated gene expression predicts response to endocrine therapy in patients with ovarian cancer. Gynecol. Oncol. 2007, 106, 461-468.

96. Irigoyen, M.; Pajares, M.J.; Agorreta, J.; Ponz-Sarvise, M.; Salvo, E.; Lozano, M.D.; Pio, R.; Gil-Bazo, I.; Rouzaut, A. TGFBI expression is associated with a better response to chemotherapy in NSCLC. Mol. Cancer 2010, 9, doi:10.1186/1476-4598-9-130.

(C) 2012 by the authors; licensee MDPI, Basel, Switzerland. This article is an open access article distributed under the terms and conditions of the Creative Commons Attribution license (http://creativecommons.org/licenses/by/3.0/). 